\title{
The Electron Microscope Enters the Realm of the Intact Cell
}

\author{
By Carol L. Moberg
}

The Rockefeller University, New York 10021

$\mathrm{T}$ his issue of the Joumal marks the fiftieth anniversary of the paper where Keith Porter, Albert Claude, and Ernest Fullam published the first electron micrograph of a complete cell (1). The cell was a fibroblast grown in tissue culture from the foregut of a chick embryo.

The March 1945 article in which this micrograph appears, "A Study of Tissue Culture Cells by Electron Microscopy," opened the world of the cell for discovery. In the authors' own words, their paper demonstrates that

. . . the extended cultured cell can be prepared for electron microscopy by relatively simple means and that such cells possess a degree of thinness which permits the requisite differential penetration of electrons. The electron micrographs ... picture structural details not heretofore noted. In view of these findings it seems probable that this new technique will make possible the study of the morphology, composition, and behavior of cell components which, because of their small size, are beyond the resolving power of the ordinary light microscope. In this latter connection particular interest attaches to the presence and distribution of "submicroscopic," cytoplasmic components previously isolated by centrifugal methods, and to the demonstration of viruses. $(1$, p. 233)

When the electron microscope was developed in the mid1930s, it offered a resolving power up to a hundred times greater than the best light microscopes. Nevertheless, scientific breakthroughs were needed to link the study of fragile cells to this microscope's harsh environment. The challenge, stated in the opening paragraph was "to devise methods by which cells could be grown and ultimately displayed on the object screen of the electron microscope and not in the process suffer excessive distortion." (1, p. 233)

The rich history preceding these breakthroughs began in a laboratory devoted to cancer research and the Rous sarcoma virus.

\section{The Importance of the Rous Sarcoma Virus to the Origins of Cell Biology}

Peyton Rous and the Chicken Sarcoma. When Rous demonstrated in 1911 (2), that a cell-free filtrate from a chicken sarcoma could give rise to tumors in healthy animals, his finding contradicted then current views about cancer. Charles Oberling later observed that tumor pathology in the early twentieth century was greatly influenced by the German school of pathologic anatomy and "was utterly opposed to any theory of an infectious origin of cancer" (3). Now that the Rous sarcoma virus (RSV) has provided so many insights into viruses and cancer, it may be difficult to imagine how such an attitude of disbelief prevailed. Yet Rous became discouraged by his futile attempts to cultivate viruses from tumors and abandoned work on this sarcoma in 1915.

James B. Murphy, Cancer Research, and the Sarcoma Agent. Rous's colleague Murphy had not accepted the idea of a viral cause of cancer. His laboratory pursued in vivo studies on cancer growth with this "transmissible agent." In 1926, he began to confirm results of English scientist W. B. Gye, who had reported cultivating an organism from tumors. In Murphy's annual report to Rockefeller's Board of Scientific Directors, he wrote that the organism could be inactivated by chloroform and revived by embryonic fluids. He then reasoned that two things were needed for a tumor: a chemical factor that determined the specific tissue to be infected and an organism common to all tumors. He concluded that the chemical factor was the chicken sarcoma agent (4). His laboratory then found that the tumor agent could be inactivated in vivo but not by ultraviolet light $(5,6)$. From this evidence, Murphy concluded the chicken tumor agent was of "a different chemical character," reinforcing his hypothesis that the sarcoma agent was not a virus.

Albert Claude and Cell Fractionation. In 1928, Claude, a recent M.D. from Belgium, applied to work with Rous, the "author of fundamental research on the tumor that bears his name" (7). Flexner replied that "cancer research at the Institute is now under Dr. Murphy who was associated with Dr. Rous in the chicken tumor work" (8).

On his arrival in 1929, Murphy assigned Claude the task of "fragmenting the tissues" to find the nature of the tumor agent. In a 1932 Journal article, he and Murphy refer to the agent as a "transmissible 'mutagen" ( $(9)$ and suggest its analogy to another substance, the one responsible for transforming pneumococcal types that was prompting Oswald Avery's research at Rockefeller and was eventually identified as DNA $(10,11)$. In 1934, Claude initiated the isolation and purification of an "active principle" from filtrates using high speed centrifugation (18,000 rpm) (12). By 1938, Claude felt he had a purified tumor agent that contained "a nucleic acid of the ribose type" (13).

About this time, Claude performed a control experiment. $\mathrm{He}$ used differential centrifugation to compare particles from sarcoma cell-free filtrates with those isolated from normal chicken embryos. To his surprise, the normal fraction, "in its main characteristics, resembles the active fraction isolated from chicken tumor extracts by the same method," except that normal tissue fractions did not produce tumors. The frac- 
tions from normal and cancerous tissues contained lipids and nucleoproteins in comparable amounts and chemical composition, and were estimated to be $70-200 \mu \mathrm{m}$ in size $(14,15)$.

The 1938 report also contained Claude's initial observations on "minute granules," the novel small particles of cytoplasmic origin he eventually sedimented from a great variety of tissues. He coined the name "microsomes" in a 1943 Science article (16) that soon stimulated the research interest of electron microscopy (see below). Claude observed that the microsomes he could isolate and characterize biochemically remained invisible. While the larger mitochondria and Golgi bodies could be stained and studied, his "highly refringent" submicroscopic bodies were beyond normal cytological techniques. He further compared the microsomes to self-perpetuating units in viruses that also depend on "ribose nucleic acid" for their activity.

Keith Porter and Cultured Cells. In 1939, Murphy brought embryologist Porter, a postdoctoral fellow from Princeton, into his laboratory to test carcinogens on the developing embryo (17). Within four years, Porter developed keen skills in manipulating live tissues and in discerning artifacts from natural structures under the light microscope. His experiences with these lilliputian worlds enabled him to achieve success on his first attempt with the electron microscope to bring an intact cell into a new realm of the visible.

In early experiments, Porter combined identical nuclei with different cytoplasms, an operation that required a dexterous hand to operate on inseminated frog eggs under a microscope with a glass needle. After following their development, he analyzed the relative roles of nucleus and cytoplasm in determining an embryo's characteristics (18).

The next experiments took place in laboratories of a sanatorium where Porter was a tuberculosis patient. While learning to diagnose cases of tuberculosis, he came upon a research project that demanded looking inside this bacterial cell. Collaborating with Diran Yegian, he examined what were considered in the literature as "pleomorphic forms" of the bacillus, either structures of the mature bacterium or of its reproductive stages. As soon as Porter tried handling these variants, he found discrepancies in different preparations of the same material. His critical scrutiny established the forms were artifacts (crushed or traumatized cells) caused by manipulating the bacilli with the platinum loop, the microtome knife, or by staining procedures $(19,20)$.

Returning to Rockefeller in 1943, Porter's new research involved repeating studies of Wilton R. Earle and co-workers at the National Cancer Institute. They had elaborated a tissue culture method for producing malignancy with methylcholanthrene in mouse fibroblasts (21). A somewhat disturbing result was that untreated cultures became malignant as frequently as treated cultures, which Earle attributed to trace contaminants in the culture. Murphy reported that these studies were being repeated in a laboratory "where there can be no contact with the carcinogenic chemical" (22). Porter spent three years confirming this spontaneous transformation of normal cells in tissue culture and he eventually used electron micrographs to track their developing malignancy (23).

\section{Going Beyond Vision: Ernest Fullam and the Electron Microscope}

Despite their research needs, Porter and Claude did not have their own electron microscope until 1948. For most of the electron microscope's developmental decade (1934-1944), these instruments were rare and highly specialized. The first commercial Siemens \& Halske (Germany) electron microscope was delivered in 1939 in Europe, and the first RCA (America) microscope in 1941. Even then, many of the available instruments during World War II were directed toward military research needs.

Biological work in Europe and in North America during this period was limited to studying silhouettes of bacteria, viruses, and fibrous proteins (24) (Table 1). Three examples of early micrographs that appeared in this Joumal are vaccinia virus (25), bacteria stained with heavy metal salts (26), and the pneumococcal capsular swelling reaction (27). These micrographs were all taken by Thomas Anderson, a National Research Council Fellow from 1940 to 1942 at the RCA Manufacturing Company, Camden, NJ. However, the Joumal's fourth and fifth articles containing micrographs, including the one being honored here, are the first views directed toward the eukaryotic cell itself $(28,1)$. These micrographs were taken for Claude and Porter by Ernest F. Fullam.

Fullam operated the first commercial RCA microscope in New York City. This was an EMB model purchased in 1941 by Albert Gessler, director of the research laboratories, at Interchemical Corporation located on Manhattan's west side. Officially, Fullam used it to examine particle size of industrial finishes (paints, printing inks, and abrasives), and, after 1942, for work on the Manhattan Project. However, Mary Schuster, an Interchemical microscopist, recounted that Gessler felt "the microscope had far more potential value for the physical study of animal tissue ... and that great forward strides could be made as a result of its use in the field of pathology, particularly in regard to cancer." As a result, Interchemical became interested in expanding its use of research instruments - electron microscope, spectrophotometer, and an experimental microtome - for biological research. This became possible in December 1943, when Interchemical received a grant from the Lillia Babbitt Hyde Foundation to support investigations in cancer research (29).

One of Albert Gessler's first projects was proposed in Claude's 1943 Science article $(15,30)$. In it, Claude hypothesized that microsomes, "like the other nucleic acid-containing structures, may be endowed with the property of selfduplication ... and [this assumption] offers a biochemical basis for the view that each vital element which contributes actively to the life of the cell has the power to reproduce its kind" $(15$, p. 455$)$. The potential relevance of these submicroscopic particles to cancer posed important questions for Interchemical's research program. Gessler thus initiated the collaboration of Fullam with Claude and Porter.

Fullam, who trained in microscopy at Cornell University, could work with the Rockefeller scientists only after regular business hours. $\mathrm{He}$ was the only one operating the micro- 
Table 1. Some Early Biological Specimens Observed by Electron Microscopy

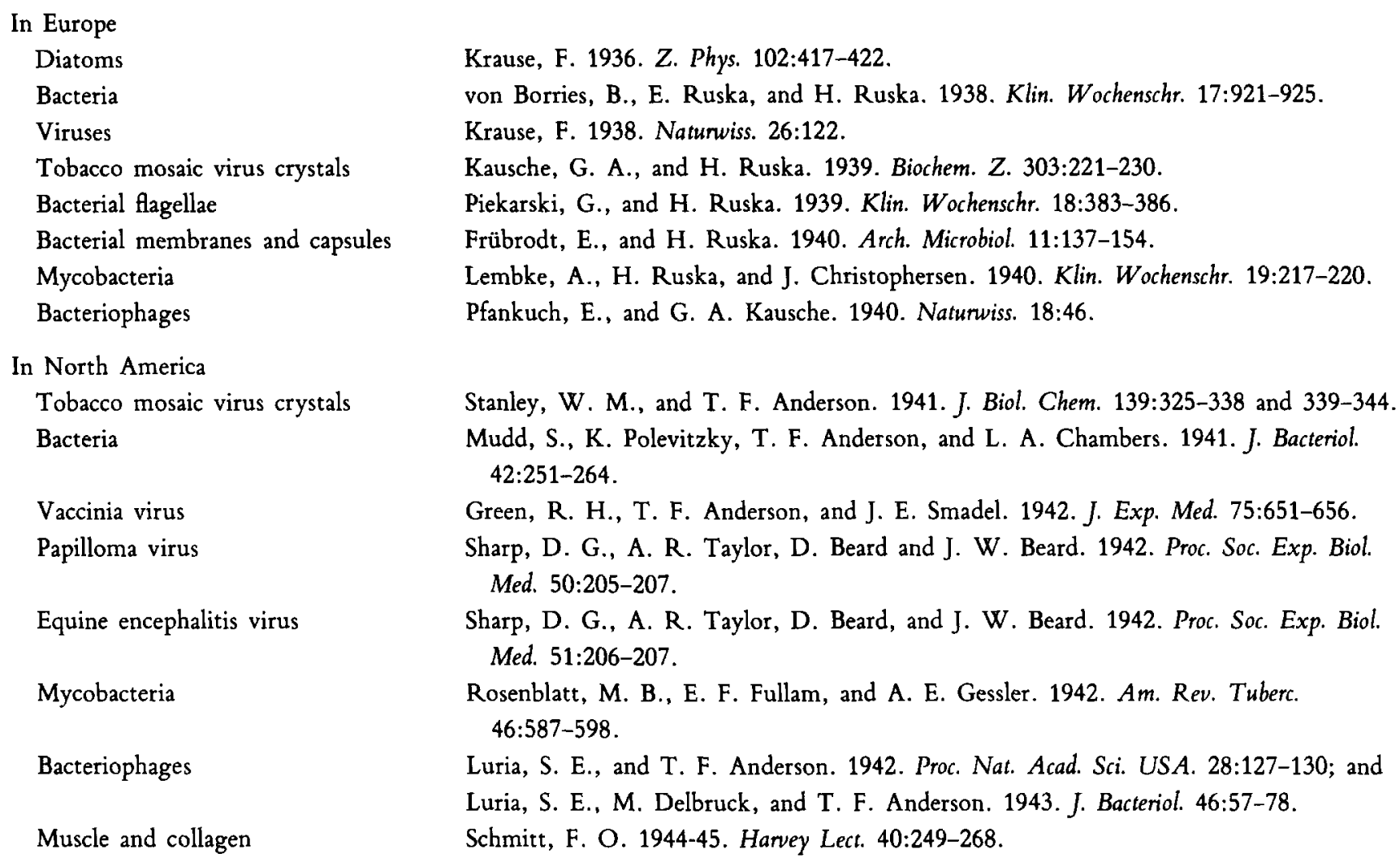

Source: Burton, E. F., and W. H. Kohl. 1946. The Electron Microscope, 2nd edition. New York: Reinhold Publishers.

scope, which seemed a good idea, since the RCA EMB, according to Fullam, was "an extremely temperamental instrument." Even then, Fullam encountered some amazing operating problems.

Alignment was extremely difficult. You had to be a tall person to get good alignment. For a short person, it was impossible unless you worked with mirrors. . . . Viewing the image as we translated the specimen was impossible in the early days because the hand controls were at the top and the viewing screen at the bottom. . . . At first we also frequently went beyond the travel of the screen so we couldn't tell where we were. Sometimes we had to take the microscope apart and realign the system to find out where we were.

Another problem involved magnetic fields. Once, I put an electric clock on the microscope and rigged it so it could be used to time exposures. I could see a beautiful image on the microscope, but with the clock on I could never get a good picture. After some experimentation, I found the magnetic field of the clock was imparting a 60-cycle oscillation to the beam, which killed all my resolution. Another time, a magnetized screwdriver lying on the table of the microscope cost me days of trying to find out why I couldn't get alignment.

There's one other little point. I soon found that kicking the microscope or slapping it sharply on the side when the high voltage wouldn't come on was very effective in returning it to operation. (31, pp. 37 and 38).

\section{A Historic Collaboration among Three Scientists}

In the absence of suitable methods or an adequate microtome to make sections, Claude and Porter began electron microscope studies with Fullam using two new techniques that required no slicing: differential centrifugation and cultured cells.

The first material to be examined under Interchemical's electron microscope was a mitochondrial fraction that Claude had isolated from a rat lymphosarcoma (28). These particles, $0.5-1.5 \mu \mathrm{m}$ in diameter, were normally too thick to permit the penetration of electrons. When Claude found that isolated mitochondria flattened out during preparation or lost some of their substance during purification, he felt electrons might be able to penetrate their internal structures. He used Formvar, a polyvinyl plastic, as the supporting membrane for this fraction, and the mitochondria were preserved with potassium dichromate and then air dried (desiccated) for a varying number of days. Claude tested four different fixatives, including osmium tetroxide $\left(\mathrm{OsO}_{4}\right)$ which he noted caused a certain amount of clumping. He described the mi- 
tochondria as surrounded by a limiting membrane that contained small internal bodies and persisted as discrete entities in the absence of the cytoplasm. Of some historical interest, the January 1945 Joumal article also included a micrograph of "microsomes" to show these particles were different from mitochondria.

The next material examined with Fullam's microscope was the intact cultured chick cell. Porter noted that "Claude wanted especially to identify the cytoplasmic origin of microsomes" (24):

On one of Claude's early visits I tagged along to see this remarkable instrument and learned such basic points as a) the specimen had to be dry and b) it had to be thin. Obviously there was nothing in this to excite a student of cells, so from the outset there was little excitement re[garding] the prospects of looking at cells. Even bacteria, as small as they are, had been shown by Stuart Mudd and [Thomas] Anderson to be too thick and there was no microtome available to cut very thin sections. Fortunately I had become involved in culturing chick cells because Dr. Murphy, our chief, was certain that if we put Claude's microsomes on cultured chick cells, we would witness a transformation to tumor cells. . . . So I began to dream about ways to get cultured cells into the e[lectron] $m$ [icroscope] (in the hope of detecting the earliest evidence of transformation) (32).

The specimens ideally had to be less than $0.1 \mu \mathrm{m}$ thick, or up to a hundred times thinner than those for light microscopes. "Everyone who has grown and observed cells in vitro knows, they have a tendency to spread out to extreme thinness, apparently in an attempt to cover as much of the substrate as possible." Porter decided "such diaphanous cells might be suitable for electron microscopy, at least in their thinner margins" (33). He offered a way to learn whether microsomes had an intracellular existence and discrete morphology in intact cells.

Porter's new procedures achieved high quality specimens for the electron microscope. He cultivated cells that would spread, grew them on a thin plastic membrane, and preserved them with osmium tetroxide. All of these enhanced the goal of obtaining contrast in thin, dry specimens. With slight modifications, many of these principles are still followed fifty years later.

Porter grew the chicken fibroblasts directly on a Formvar film supporting membrane and fed them by diffusion through that membrane. Working under a dissecting microscope, he then removed the cells intact, first peeling the Formvar film from the glass cover slips and then transferring them and the supporting film underwater onto a wire mesh grid that held specimens in the electron microscope. When the grid, held between the points of a watchmaker's forceps, was removed from the water and drained on filter paper, the Formvar stretched and adhered to the grid. In this method, cells that would naturally be surrounded by salt solutions had little contact with distilled water even during the transfer from the culture to the wire grid. The plastic membrane thus eliminated surface tension on the cells. These delicate techniques are described briefly in the 1945 paper, but they were later illustrated and elaborated by Porter. (Fig. 1, from reference 34 ).
As Porter's experiments with tubercle bacilli showed, fixatives and slicing techniques created bizarre structures. Fixation for electron microscope specimens was even more challenging, since the specimens were examined in a vacuum and had to withstand removal of liquids without losing their shape. Of the four fixatives tested in this 1945 experiment,

... osmium tetroxide has been the most satisfactory in that it yields what impresses one as being the most truthful picture of the cell. It seems not to distort the cells and it largely prevents subsequent dehydration effects. It may serve also as a differential stain, for by its action some cellular structures are apparently rendered more electron-scattering than others

... micrographs of cells treated with fixatives other than osmium tetroxide provide excellent illustrations of alterations that can arise from fixation (1, p. 243).

The March 1945 paper credited English cytologists Strangeways and Canti who showed in 1927 that $\mathrm{OsO}_{4}$ produced "an almost perfect preservation of the cell and its internal structure" for dark field microscopy (35). However, applying osmic acid as a vapor from a $2 \%$ solution was a technique introduced by Porter.

George Palade, who joined the Murphy laboratory in 1946, commented as follows on the twenty-fifth anniversary of this micrograph: "It is clear that the high quality of the micrographic evidence presented in these articles, the high contrast, and the sharp definition of the structures studied were due to a combined effect of fixation and staining of cellular membranes by $\mathrm{OsO}_{4}$ and of . . . prolonged fixation and subsequent washing" (36). This fixation and washing led to the degradation and subsequent extraction of the proteins of the cytoplasmic matrix, which reduced the thickness of the cell specimens and enhanced the contrast of membrane-bound subcellular components.

\section{First Glimpses inside the Cell}

Porter recalled the moments after the first cultured cells appeared under the electron microscope:

Within a short time we discovered on one grid-which had only three or four cells on it -a cell in an opening in the grid, and it became the most micrographed cell in history. It was wonderful, believe me, we had never seen anything like it. Men have visited the moon . . . but we were the first . . to see particles, to see structures that the light microscope had not been able to resolve. And there were Claude's microsomes, and there was the lacework of [what] eventually came to be known by that horrendous term "endoplasmic reticulum" (37).

Porter was later to diagram the endoplasmic reticulum (Fig. $4 a$ in reference 38 ), and he suggested:

This endoplasmic material of the electron micrograph is the small particle fraction of broken-up cells, described by Claude, [and] this connection with cytoplasmic ribose nucleotides is strengthened by some recent observations that the ribose nucleic acid within rat liver cells is definitely concentrated in the microsomal or small particle fraction isolated by centrifugal methods (39).

The end point of the microsome story came a decade later. 
Palade and Philip Siekevitz positively identified "Claude's microsomes" as fragments of endoplasmic reticulum, most of them bearing ribosomes on their membranes $(40,41)$.

This "most micrographed cell" is actually a montage of five micrographs at a magnification of 1,600. The field of view in the RCA EMB was not large enough to include the entire cell, so five individual pictures were joined into a single image. Porter, Claude, and Fullam published a standard photomicrograph alongside this electron micrograph (magnification, $1,250)$ to emphasize the light microscope's limited resolving power.

The micrograph emitted much more structural information than the authors ever expected, and they were confronted with how to interpret and describe what they saw. Some of their observations of the subcellular world remain cautiously exacting. In place of a Results section, they titled their descriptions "Observations":

... the adequacy of the electron micrograph technique for the demonstration of the finest structural features in other areas [than the nucleus] is beyond question. It is not at present possible to do more than point out the more obvious details that appear in the various parts of the cell.
Cell Outline: variety of irregularities . . . associated with migration . . . jagged points under tension . . . finger-like processes not under tension . . . tentacles active in advance of migrating cell borders.

Ground Substance: particulate elements . . [perhaps] microsomes . . lace-like reticulum . . vesicle like bodies.

Mitochondria: impressive clarity . . . masses of greater density and variable size appear distributed along the body.

Golgi Bodies: dense bodies characterized by rather angular outlines.

Cell Nuclei: too thick . . . for detailed electron microscope study.

Intercellular Relationships: claw-like processes . . . not at present interpretable.

Nerve Ending: an ameboid nerve ending or growth cone.

The paper's conclusions articulate the authors' keen awareness of a new world in science that had just opened to them:

Micrographs taken at the conservative magnification of 1600 are so packed with detail that the smaller clearly resolved structural features are not easily seen until the pictures are enlarged two or three times. ... It appears, from these early observations that the cultured cell, when selected for thinness, lends itself well to electron microscopy $(1$, p. 242$)$.
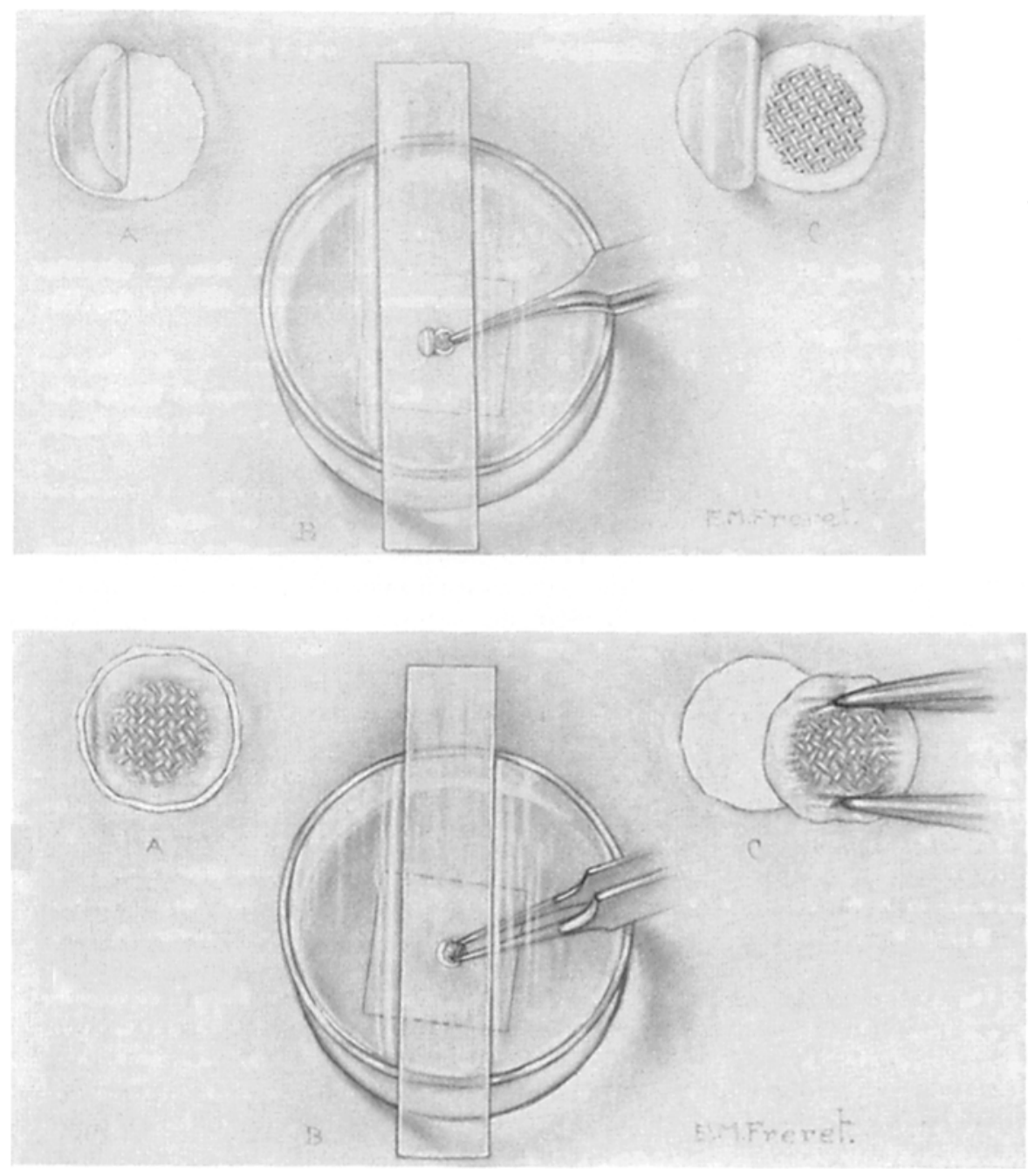

Figure 1. Drawings depict steps to transfer cultured, fixed, and washed cells to electron microscope grids. All manipulations are performed under water with a watchmaker's forceps and under a dissecting microscope at a magnification of about 12 diameters. In both illustrations, $B$ shows the unenlarged petri dish, cover glass, and narrow slide placed over the assembly to eliminate distortions introduced by surface waves in the water bath. (Top) The cells are grown on glass slides coated with Formvar. In $A$, when cells of adequate thinness appeared among the cultured population, a flap is cut out to cover a grid ( $3 \mathrm{~mm}$ in diameter). This small disc is peeled back from the slide with fixed cells in place. In $C$, the flap of film is peeled back further and a small wire mesh grid is placed in the opening. (Bottom) In $A$, the Formvar flap containing the cultured cells is brought back over the grid and held with forceps, as in $B$ and $C$. The combination of grid, film, and cells is lifted with forceps, drained of excess water on filter paper, and then stored in a dry petri dish (from reference 34, pp. 733 and 734). 


\section{A New Thrust in Cell Biology: Subcellular Structure-Function Analyses}

Electron microscopy of thinly spread cultured cells, demonstrated in this micrograph and Journal article, was a step toward the longstanding goal to identify and locate the Rous sarcoma agent. In 1947 Claude, Porter, and Edward Pickels grew two strains of RSV in cultured chick cells (42). Their micrographs depict viral particles dispersed singly or in pairs throughout the cytoplasm in chicken tumor $I$, and in com. pact patches in chicken tumor $X$. They tentatively identified the RSV particles because they were of regular size, equal density, and absent from control cells. The next year Porter and Helen $\mathbf{P}$. Thompson demonstrated virus-like particles on the surface and inside mammary tumor cells of mice (39). Although tools for definitive identification of viruses were still missing in the mid-1940s, these early micrographs on virus-infected cells did much to enhance the value of cultured cells in electron microscopy.

While the cultured cell has not lost its glamor after fifty years, its limited usefulness for electron microscopy was recognized very early. Many cell types could not be grown in culture, skills of great dexterity were required, and, more important, much thinner specimens and sections were needed for electron penetration of the thicker cell components. Claude and Fullam's frustrating experience with liver cell sections in 1946 convinced Claude that a new microtome was needed for the electron microscope $(43,44)$. The next decade saw a great improvement in techniques, including the development of an ultramicrotome in the instrument shop at Rockefeller.

The publication of this landmark micrograph of a complete cell kindled the study of subcellular components. Soon scientists would isolate subcellular fractions defined with cytologic criteria, determine their biochemical composition, and measure their biological activities. With this study, the integration of cell structure and function was stimulated. The modern science of cell biology had begun.

Many individuals provided valuable resources for this article: Mary Bonneville, Philippa Claude, Christian de Duve, Ernest Fullam, George Palade, Lee Peachey, Philip Siekevitz, Frederick Seitz, and Ralph Steinman. The Rockefeller University Archives provided photographs of Drs. Porter and Claude. Dianne Fullam provided the photograph of Ernest Fullam.

\section{References}

1. Porter, K.R., A. Claude, and E.F. Fullam. 1945. A study of tissue culture cells by electron microscopy. J. Exp. Med. 81: 233-246.

2. Rous, P. 1911. A sarcoma of the fowl transmissible by an agent separable from the tumor cells. J. Exp. Med. 13:397-411.

3. Oberling, C. 1961. In honor of Peyton Rous. Perspect. Virol. II:1-4.

4. Murphy, J.B. 1925-26. Scientific Reports to the Board of Scientific Directors of the Rockefeller Institute for Medical Research. 14:37-38. Rockefeller University Archives, RG 439. Rockefeller Archive Center.

5. Duran-Reynals, F., and J.B. Murphy. 1929. Properties of the causative agent of a chicken tumor. I. The specific fixation by tissues of susceptible animals. J. Exp. Med. 50:315-326.

6. Sturm, E., F.L. Gates, and J.B. Murphy. 1932. Properties of the causative agent of a chicken tumor. II. The inactivation of the tumor-producing agent by monochromatic ultra-violet light. J. Exp. Med. 55:441-444.

7. Claude, A. Excerpt from 21 December 1928 application (translated from the French). Rockefeller University Archives, RG 450C571, Box 1. Rockefeller Archive Center.

8. Simon Flexner to Jules Duesberg. 19 December 1928. Rockefeller University Archives, RG 450C571, Box 1. Rockefeller Archive Center.

9. Murphy, J.B., E. Sturm, A. Claude, and O.M. Helmer. 1932. Properties of the causative agent of a chicken tumor. III. Attempts at isolation of the active principle. J. Exp. Med. 56: 91-106.

10. Steinman, R.M.. and C.L. Moberg. 1994. The experiment that transformed biology: discovering the genetic role of DNA.
J. Exp. Med. 179:381-384.

11. McCarty, M. 1994. A retrospective look: how we identified the pneumococcal transforming substance as DNA. J. Exp. Med. 179:385-394.

12. Murphy, J.B. 1934-35. Scientific Reports to the Board of Scientific Directors of the Rockefeller Institute for Medical Research. 23:51. Rockefeller University Archives, RG 439. Rockefeller Archive Center.

13. Claude, A. 1938. Concentration and purification of chicken tumor I agent. Science (Wash. DC). 87:467-468.

14. Claude, A. 1938. A fraction from normal chick embryo similar to the tumor producing fraction of chicken tumor I. Proc. Soc. Exp. Biol. Med. 39:398-403.

15. Claude, A. 1940. Particulate components of normal and tumor cells. Science (Wash. DC). 91:77-78.

16. Claude, A. 1943. The constitution of protoplasm. Science (Wash. DC). 97:451-456.

17. Murphy, J.B. 1939-40. Scientific Reports to the Board of Scientific Directors of the Rockefeller Institute for Medical Research. 28:74-75. Rockefeller University Archives, RG 439. Rockefeller Archive Center. Unpublished experiments.

18. Porter, K.R. 1941. Diploid and androgenetic haploid hybridization between two forms of rana pipiens, schreber. Biol. Bull. $80: 238-264$.

19. Yegian, D., and K.R. Porter. 1944. Some artifacts encountered in stained preparations of tubercle bacilli. I. Non-acid-fast forms arising from mechanical treatment. J. Bacteriol. 48:83-91.

20. Porter, K.R., and D. Yegian. 1945. Some artifacts encountered in stained preparations of tubercle bacilli. II. Much granules and beads. J. Bacteriol. 50:563-575. 
21. Earle, W.R., L.R. Crisp, and A. Nettleship. 1943. Production of malignancy in vitro. J. Natl. Cancer Inst. 4:131-248.

22. Murphy, J.B. 1943-44. Scientific Reports to the Board of Scientific Directors of the Rockefeller Institute for Medical Research. 32:75. Rockefeller University Archives, RG 439. Rockefeller Archive Center.

23. Murphy, J.B. 1943-44, 1944-45, and 1945-46. Scientific Reports to the Board of Scientific Directors of the Rockefeller Institute for Medical Research. 32, 33, 34. Rockefeller University Archives, RG 439. Rockefeller Archive Center. Unpublished experiments.

24. Pease, D.C., and K.R. Porter. 1981. Electron microscopy and ultramicrotomy. J. Cell Biol. 91:287s-292s.

25. Green, R.H., T.F. Anderson, and J.E. Smadel. 1942. Morphological structure of the virus of vaccinia. J. Exp. Med. 75: 651-656.

26. Mudd, S., and T.F. Anderson. 1942. Selective 'staining' for electron micrography. J. Exp. Med. 76:103-107.

27. Mudd, S., F. Heinmets, and T.F. Anderson. 1943. The pneumococcal capsular swelling reaction, studied with the aid of the electron microscope. J. Exp. Med. 78:327-332.

28. Claude, A., and E.F. Fullam. 1945. An electron microscope study of isolated mitochondria. J. Exp. Med. 81:51-62.

29. Schuster, M. 1946. High-speed microtoming. Interchemical Review. 5:31-41.

30. Bonneville, M. 1985. Pioneers in Modern Biology: Keith Roberts Porter and the Electron Microscopy in Cell Biology. Videotape interview courtesy of Mary Bonneville.

31. Reisner, J.H. 1986. Reflections: Ernest F. Fullam reminisces. EMSA Bulletin. 16:35-43.

32. Porter, K.R. n.d. Cell biology at Rockefeller Institute. Manuscript in private papers of K.R. Porter, University of Pennsylvania.

33. Porter, K.R. 1987. Electron microscopy of cultured cells. In The American Association of Anatomists, 1888-1987. John
Pauly, editor. Baltimore: Williams \& Wilkins. pp. 59-67.

34. Porter, K.R. 1953. Observations on a submicroscopic basophilic component of cytoplasm. J. Exp. Med. 97:727-750.

35. Strangeways, T.S.P., and R.G. Canti. 1927. The living cell in vitro as shown by dark-ground illumination and the changes induced in such cells by fixing reagents. Q. J. Microsc. Sci. 71:1-14.

36. Palade, G.E. 1971. Albert Claude and the beginnings of biological electron microscopy. J. Cell Biol. 50:5D-19D.

37. Porter, K.R. 7 October 1970. Remarks on receiving the Louisa Gross Horwitz Prize with Albert Claude and George Palade. Rockefeller University Archives. RG 365.3. Box 4, Folder 1. Rockefeller Archive Center.

38. Porter, K.R., and H.P. Thompson. 1948. A particulate body associated with epithelial cells cultured from mammary carcinomas of mice of a milk-factor strain. J. Exp. Med. 88:15-24.

39. Porter, K.R., and H.P. Thompson. 1947. Some morphological features of cultured rat sarcoma cells as revealed by the electron microscope. Cancer Research. 7:431-438.

40. Palade, G.E., and P. Siekevitz. 1956. Pancreatic microsomes: an integrated morphological and biochemical study. J. Biophys. Biochem. Cytol. 2:671-690.

41. Palade, G.E., and P. Siekevitz. 1956. Liver microsomes: an integrated morphological and biochemical study. J. Biophys. Biochem. Cytol. 2:171-200.

42. Claude, A., K.R. Porter, and E.G. Pickels. 1947. Electron microscope study of chicken tumor cells. Cancer Research. $7: 421-430$

43. Claude, A., and E.F. Fullam. 1946. The preparation of sections of guinea pig liver for electron microscopy. J. Exp. Med. 83:499-504.

44. Claude, A. 1950. Studies on cells: morphology, chemical constitution, and distribution of biochemical functions. Harvey Lect. 1947-1948. 43:121-164. 